\title{
Competing paradigms in the debate about agricultural pricing policy ${ }^{1}$
}

\author{
Christopher Colclough
}

\section{Of Price and Policy Distortions}

This article argues that the importance of price policy has been underplayed in many structuralist analyses of development problems. This, however, is not because such writers have held that incentives are unimportant - rather that they have assumed that the extent of deviation of domestic from 'world' prices is less than has typically been the case. Equally, the article argues that the 'discovery' of the extent of price distortions in many African economies has resulted in price policy and the opening up of domestic markets to competitive forces being reasserted as the core elements in any recovery programme for African economies. The danger of this lies not in the increased attention given to price policy per se, but rather with the set of intellectual baggage which a central concern with price often carries with it. Much theoretical and empirical work in the structuralist tradition has shown the ways in which the 'special case' of neoclassical theory is insufficient as a framework for understanding development problems. The heat of the debate (e.g. IDS 1983 versus World Bank 1981) stems partly from fears that this framework is being reasserted as the dominant paradigm - at least as regards the policy debate - and that part of what has been learnt over the past decade risks being rejected for inadequate reasons.

In order to provide some basis for the above judgements, it is worthwhile examining the treatment of price policy in some prominent examples of structuralist writings. Those selected here - on the grounds of their representativeness and importance - are the ILO Report on Kenya [ILO 1972] and the joint IDS/World Bank volume, Redistribution with Growth, published in 1974. The main issues of importance in pricing policy concern the need to stimulate the output of the tradeable goods sectors as against services, to shift the internal terms of trade towards agriculture, and to permit a structure of domestic agricultural prices which is not funda-

\footnotetext{
The author is grateful for comments on an earlier draft from Charles Harvey, Martin Godfrey, Michael Lipton, and Stanley Please.
}

mentally out of line with international prices for the same commodities. The ways in which these issues were addressed in the above volumes will now be briefly discussed.

The ILO Kenya report acknowledged that one of the important ways in which the government could assist agricultural development was by raising the producer price of agricultural commodities. Nevertheless, the report gave little space and emphasis to the analysis of this problem (pp158-9). The prices of some commodities - maize, milk, sugar, beef and cotton - had been raised in 1972 and it was felt that there was limited scope for further increases. The report judged that the prices of export crops were mainly determined by world market prices - yet evidence on the between world relationship and domestic producer prices was not presented, and the question of currency depreciation was not discussed. For food products, the judgement was similar: here the prices were fixed by government, and they had generally been above export parity prices except in the case of beef. Furthermore, while some smallholders would benefit from increased food prices, the main recipients would have been the large farmers, with the losers being poor rural and urban households in whose budgets food featured large. Thus, agricultural output was expected to be more sensitive to the provision of better extension, research and credit facilities, and land redistribution towards smallholders, than to changes in pricing policies.

In retrospect it does appear that Kenya was following a reasonably efficient set of agricultural pricing policies at that time [Sharpley 1984]. Over the 1970s there was close conformity between international and producer prices for export crops, converted at the official exchange rate. Price trends favoured exporters (with the exception of beef), rather than producers of food, particularly until 1978. Yet even for food, between 1972 and 1978 domestic border prices exceeded world border export prices by a significant margin. Thus, without begging the question of the

WDS Bullerin. 1985, vol if no 3, Institute of Development Studies. Sussex 
relationship between the shadow and official exchange rates - a matter which has not been conclusively resolved in the literature - a move to bring domestic producer prices into line with world export prices at the official exchange rate would have involved reducing, rather than increasing, the prices paid to smallholders in comparison with those which were actually paid. Nevertheless, even though its conclusions on the matter of agricultural pricing policy were broadly correct at that time, the report gave only limited attention to this area of policy as part of its implied long-term strategy; by implication, pricing policy could be left to take care of itself.

\section{Redistribution, Growth and Prices}

Since it represents a more general theoretical statement of the structuralist position, it is worth considering the treatment given to agricultural prices in Redistribution with Growth. The main theoretical hypothesis of this volume was the Ricardian one that income increments arising from economic growth accrue mainly to the owners of assets - capital, land and skills - and to those whose entry into wage labour is facilitated by the process of asset growth. Since, however, the increment to wage labour in ldcs is rarely as large as the increment to the labour force, it is reasonable to suppose that those without assets may be largely unaffected by economic growth, and that the numbers experiencing such poverty will continue to grow. Thus, since asset distribution in developing countries is typically even more unequal than income distribution, the benefits of growth will only begin to reduce poverty significantly if the poor themselves are given heightened access to productive resources beyond that delivered by the market process. This argument, therefore, implied that the distribution of assets should be purposively and significantly changed over time.

The book's prognosis essentially involved strategies which would protect economic growth, while securing asset redistribution at the same time. These comprised a series of policy interventions to influence the level and growth of income to different groups in society. They included interventions in factor markets, in the ownership and control of assets, in the taxation of personal income and wealth, in the provision of public consumption goods, in commodity markets, and in technological innovations. These analyses, however, did not give much attention to agricultural pricing policy. Consider the following quotation:

Family income (of peasant households) is basically constrained by the availability of complementary physical inputs ... and by the prices received for their output. Since the scope for manipulating farm prices ... is limited, government policy must attempt to provide access to an approximate mix of physical and financial inputs (and technical knowhow) in order to raise incomes in this sector. This is unlikely to be achieved solely through changes in relative prices, although they facilitate the productive use of existing assets.

[World Bank/IDS 1974: 4]

The reasons why the authors of Redistribution with Grow'th believed there to be little scope for manipulating farm prices in general were not clearly stated. Implicitly at least, th is omission implied a view that exchange rates are not seriously over-valued, and that world prices, net of transport and marketing costs, do by and large get passed on to producers. If either of these conditions were not satisfied it would not be correct to argue that little could be done to affect farm prices as measured in domestic currency - that is, unless one also took the view that for political reasons an effective devaluation is generally unattainable, or that nominal protection coefficients for both food and export crops could not be raised, or lowered, as the case may be. We shall return to these possibilities later.

Although Redistribution with Growth remained silent about pricing policy in the export sector, a little was said about pricing policy problems for wage goods, including food. The analysis of this issue, however, also suggested little room for manoeuvre. In the case of food products the book implied that, in general, increases in their prices would be desirable: the terms of trade between agriculture and other sectors had been biased against the former as a result of public policy (pp 124-5), and some increases in food prices were needed in many cases, even though this would tend to decrease the real incomes of wage-earners and the food-deficit self-employed in both the formal and informal sectors.

This last consideration leads to the view that one might seek price support for agricultural products based upon first, the extent of their production by the poorest farmers, and second their proportional importance in low-income family budgets. A selective approach would thus be implied, taking into account the secondary employment effects of increasing product prices, for different products in different countries. Taken together, these analyses imply that, while prices are important, they are only one element in the process of eliciting a desirable pattern of production and distribution, and that the scope for changing the prices received by farmers is in any case rather limited.

\section{Primacy of Prices}

The World Bank, and other sources, have recently 




Production incentives include availability of consumer goods to rural producers.

challenged these views strongly. In its report on Accelerated Development in sub-Saharan Africa, the crisis facing agricultural production in SSA is well documented: it is shown that agricultural production growth rates declined during the 1970s to less than rates of population growth; agricultural exports stagnated, and the shares of world trade captured by Africa for many agricultural commodities declined over the period; food production per capita also declined over the 1970s, and food imports increased to fill the gap - in some cases, dramatically so. The main factors which led to this production crisis are said to be drought, the disruptions caused by wars and civil strife, rapid population growth which has increased the intensity of the land constraint, neglect of agricultural investment by governments and donors, 'bad' pricing policies, the non-availability of necessary inputs and inefficient marketing arrangements.

In tackling this list of problems, the report deliberately concentrates upon policy reform proposals which are viewed to be necessary for their amelioration. It acknowledges that investment priorities in agriculture are equally important ( $\mathrm{p50}$ ) but chooses to concentrate on policy questions. Four priorities are selected: a renewed emphasis upon smallholder production, changing existing incentives structures, expanding agricultural research, and emphasising quick-yielding activities in irrigated agriculture. Among these, the incentives question is believed to be most important: more space is devoted to this issue than to the other three combined, and the recommendations are more crisp and better researched in this than in the other policy areas. The report quotes evidence from microlevel studies which point to 'the almost over-riding importance of producer prices in affecting production often cutting across the quality of technical packages and extension services' ( $p 55$ ). It cites also the large amount of micro-evidence which indicates substantial farmer responsiveness to price.

Data are presented which indicate that public policy has discriminated against farmers in African countries. Table 1 reproduces part of this evidence. It shows that over the 1970s for nine crops in 12 SSA countries, farmers have typically received far less than the 
international price for their products - after allowing for transport, marketing and processing costs. These ratios reflect, therefore, the implicit level of taxation of export crops. The ratios are calculated at official exchange rates. Making allowance for the extent of currency over-valuation would, therefore, reduce these ratios still further. The Bank estimates that in a good number of the countries shown, the combined effects of taxation, inefficient marketing arrangements (since actual costs are deducted before calculation of the ratios) together with currency over-valuation, have been such as to reduce the level of returns to producers below half of their real value as measured by international prices. It is for these and other reasons that the Berg report puts prices at the centre of its agenda for policy reform.

As indicated above, the report does make reference to a very wide range of other policy problems in African states. The prominence given to price policy, however, represents a clear shift in emphasis as compared with that of Redistribution with Growth, i.e., it not only argues that prices are important, but it argues that something can be done about them - even in the current politico-economic circumstances facing African states. The remainder of this article argues that the task of achieving such policy change will be more difficult than is often acknowledged. It also suggests the type of evidence which is required before further progress in these matters can easily be made.

\section{Problems of Tax and Tax Reduction Impact}

In one sense, mere inspection of the data in Table $l$ is sufficient to suggest a prima facie case for the need to increase the returns to farmers in Africa. Effective tax rates of over 50 per cent cannot easily be justified on a group of producers, some of whom comprise a substantial proportion of the pocrest 30 per cent of the population. Equally, to the extent that producers are price responsive, to deny them half the real returns accruing from increased sales must certainly prevent agricultural production from being as high as it otherwise might.

There are two particular issues, however, which have been under-stressed in earlier discussions. The first is that public revenues from export taxes are - or at any rate were - a major source of finance to the public sector. Given the size of existing budget deficits, substantial short-term adjustment of these tax rates has usually been difficult or even impossible.

The problem has been further compounded since 1979, when - unlike the earlier period - terms of trade facing exporters of agricultural commodities have declined substantially. A situation of falling agricultural prices and rising public sector deficits is hardly one in which the prospect of reducing tax rates on a major revenue source is easy to achieve without significant costs, e.g. to inflation rates. Even for crops where the price elasticity of supply is very high, and where the revenues arising from increased sales would partly - or even fully - compensate the public sector for lower tax rates, the lag in supply response for most crops must imply that the short-term effects on public revenues would be strongly negative. Thus, the possibilities for reducing existing levels of taxation on export crops will vary significantly between countries. Inter alia they will depend upon the proportional importance to the public budget of revenues from a particular crop, on the elasticity of its supply, and on its likely production lag in response to price changes. Distributional questions would also be important including the extent to which the crops in question generated a substantial part of smallholder incomes as would the condition that increases in national or continental supply should not significantly reduce world market prices of the crops concerned. The answers to these questions will vary substantially between different crops and countries. More data and analysis at the country level are required before one could conclude firmly that this area of policy reform is generally a feasible (and not just a desirable) strategy for the short and medium terms over the sub-continent as a whole.

A second issue of importance is the extent to which high levels of domestic taxation do help to explain the poor performance of agricultural production in Africa over the 1970s as compared with earlier decades. The dat a in Table 1 show that in one third of the cases some reduction in effective taxation rates was achieved between 1976 and 1984, while in the remainder of cases rates were increased over the period. This trend may be thought compatible, at least, with the declining agricultural production record over the 1970s. Nevertheless, taxation of export crops is not a new phenomenon in Africa. Governments during both the colonial and post-colonial periods have used export taxes as a source of domestic revenue. The Accelerated Development Report provides no evidence as to whether such taxation during the 1970s, or subsequently, has been greater than in the past. However, the data in Table 2 (not directly comparable with Table 1 , since, here, marketing and transport costs are not deducted) indicate that effective taxation rates have been high for many years, and that for more than half of the countries and crops shown the trend has been towards reducing rates of taxation over the 1970s as compared with earlier periods. However, more data for earlier years and other countries are needed to increase the representativeness of the sample. Meanwhile, it remains an open question as to whether effective rates of taxation are important in explaining the poor agricultural performance of SSA during the 1970 s as compared with the previous decade. 


\section{Nominal Protection Coefficients ${ }^{1}$ of Selected Export Crops}

\begin{tabular}{|c|c|c|c|c|c|}
\hline \multirow[t]{2}{*}{ Crop } & \multirow[t]{2}{*}{ Country } & \multicolumn{2}{|c|}{$1971-75$} & \multicolumn{2}{|c|}{$1976-80$} \\
\hline & & Coefficient & Observations & Coefficient & Observations \\
\hline \multirow[t]{4}{*}{ Cocoa } & Cameroon & 0.37 & 2 & 0.45 & 2 \\
\hline & Ghana & 0.47 & 5 & 0.40 & 4 \\
\hline & Ivory Coast & 0.56 & 2 & 0.38 & 1 \\
\hline & Togo & 0.50 & 5 & 0.25 & 4 \\
\hline \multirow[t]{7}{*}{ Coffee } & $\begin{array}{l}\text { Cameroon } \\
\text { (Arabica) }\end{array}$ & 0.72 & 2 & 0.60 & 2 \\
\hline & Cameroon & & & & \\
\hline & (Robusta) & & & 0.36 & 1 \\
\hline & Ivory Coast & 0.68 & 1 & 0.36 & 1 \\
\hline & Kenya & 0.94 & 1 & $\ldots$ & . \\
\hline & Tanzania & 0.80 & 5 & 0.59 & 4 \\
\hline & Togo & 0.42 & 5 & 0.23 & 4 \\
\hline \multirow[t]{9}{*}{ Cotton } & Cameroon & & & 0.79 & 1 \\
\hline & Ivory Coast & 0.79 & 1 & 1.05 & 1 \\
\hline & Kenya & 1.07 & 1 & & \\
\hline & Malawi & 0.68 & 5 & 0.75 & 2 \\
\hline & Mali & 0.55 & 2 & 0.44 & 4 \\
\hline & Senegal & 0.65 & 2 & & . \\
\hline & Sudan & 0.78 & 2 & 0.60 & 1 \\
\hline & Togo & 0.62 & 5 & 0.79 & 4 \\
\hline & Upper Volta & $\cdots$ & $\cdots$ & 0.79 & 1 \\
\hline \multirow[t]{5}{*}{ Groundnuts } & Malawi & 0.79 & 5 & 0.59 & 2 \\
\hline & Mali & 0.57 & 2 & 0.43 & 4 \\
\hline & Senegal & 0.48 & 4 & 0.66 & 4 \\
\hline & Sudan & 0.85 & 3 & 0.67 & 1 \\
\hline & Zambia & 0.70 & 5 & 0.71 & 4 \\
\hline \multirow[t]{3}{*}{ Maize } & Kenya & 0.96 & 1 & 1.33 & 1 \\
\hline & Malawi & 1.68 & 5 & 1.34 & 2 \\
\hline & Zambia & 0.72 & 5 & 0.78 & 4 \\
\hline \multirow[t]{2}{*}{ Sesame } & Sudan & 0.83 & 1 & 0.59 & 1 \\
\hline & Upper Volta & . & . & 0.88 & 1 \\
\hline Tea & Kenya & 0.89 & 1 & . & . \\
\hline \multirow[t]{2}{*}{ Tobacco } & Malawi & 0.42 & 5 & 0.28 & 2 \\
\hline & Zambia & 1.09 & 5 & 0.88 & 4 \\
\hline Wheat & Kenya & . & . & 1.43 & 1 \\
\hline
\end{tabular}

Note: ${ }^{1}$ Defined as the price paid to the producer divided by the amount he would have received had he sold his crops at the world market price, minus transport, marketing and processing costs.

Source: World Bank 1981: 56. 
Percentage of World Market Prices Received by Farmers, by Crop and Country

\begin{tabular}{|c|c|c|c|c|}
\hline Crop & Country & Period & $\begin{array}{c}\text { No. of } \\
\text { Observations }\end{array}$ & $\begin{array}{c}\text { Percentage of } \\
\text { World Price Received }\end{array}$ \\
\hline \multirow[t]{7}{*}{ Cotton } & Nigeria & $1950-60$ & 10 & 20 \\
\hline & & $1960-70$ & .10 & 23 \\
\hline & & $1970-77$ & 4 & 55 \\
\hline & Sudan & $1961-62$ & 2 & 44 \\
\hline & & $1971-72$ & 2 & 49 \\
\hline & Tanzania & $1966-70$ & 4 & 63 \\
\hline & & $1970-75$ & 5 & 50 \\
\hline \multirow[t]{5}{*}{ Cocoa } & Nigeria & $1950-60$ & 10 & 63 \\
\hline & & $1960-70$ & 10 & 52 \\
\hline & & $1970-77$ & 7 & 60 \\
\hline & Ghana & $1950-59$ & 10 & 51 \\
\hline & & $1960-64$ & 5 & 66 \\
\hline \multirow[t]{5}{*}{ Groundnuts } & Nigeria & $1950-59$ & 10 & 54 \\
\hline & & $1960-69$ & 10 & 48 \\
\hline & & $1970-76$ & 6 & 57 \\
\hline & Senegal & $1962-69$ & 8 & 45 \\
\hline & & $1970-73$ & 3 & 34 \\
\hline \multirow[t]{3}{*}{ Palm Oil } & Nigeria & $1950-59$ & 10 & 71 \\
\hline & & $1960-69$ & 10 & 61 \\
\hline & & $1970-72$ & 2 & 53 \\
\hline \multirow[t]{3}{*}{ Palm Kernels } & Nigeria & $1950-59$ & 10 & 62 \\
\hline & & $1960-69$ & 10 & 49 \\
\hline & & $1970-76$ & 6 & 77 \\
\hline
\end{tabular}

Source: Calculated from Bates 1981, Appendix B, pp136-45

\section{Real Exchange Rates and Real Grower Prices}

One problem for the above analysis, of course, is its partial nature. Supply responsiveness cannot be judged only with respect to effective rates of taxation. It is dependent also on movements in the real international price of the commodities in question, upon movements in the real exchange rate, upon levels of domestic inflation, and upon cross elasticities of supply with regard to other crops. Thus, if real exchange rates have increased over time, the resulting decrease in returns to farmers, even during periods when international prices of commodities remained constant in real terms, may more than compensate for any reduction in effective rates of taxation facing their products. Thus, the other central aspect of pricing policy which affects farmers' returns is the price of foreign exchange.
It is now clear that in many African count ries the price of foreign currency is too low. This situation is the result of domestic inflation rates consistently exceeding the world inflation rate, in circumstances where the exchange rate has remained unchanged, or has depreciated insufficiently to restore earlier price relativities. This has meant that imports are typically cheaper than they should be and, since the price of Africa's exports are generally fixed in terms of foreign exchange, that the domestic revenues accruing to exporters are too low. Reassertion of the 'true' price of imports and exports would allow a move away from tariffs and direct controls towards price as a means of limiting import demand, an increase in the domestic currency earnings of exporters and, via these price effects, an increase in both export production and earnings of foreign exchange. It is for these reasons 
that the Bank believes that "trade and exchange rate policy is at the heart of the failure to provide adequate incentives for agricultural production and exports in much of Africa' [World Bank 1981: 24], that 'devaluation is a powerful tool for restructuring (these) relative prices and incentives' [op. cit.: 30$]$ and that in this context the exchange rate 'is one of the most pervasive instruments of development policy' [Please and Amoako 1983: 23].

The problems with this analysis relate not to the judgement that exchange rates in Africa are presently over-valued, but rather to whether or not nominal devaluation will succeed -- in existing politicoeconomic circumstances - in achieving a real effective downward adjustment of the exchange rates, such that the benefits mentioned above can be captured. It is well known that for this to be achieved it is necessary that domestic prices should not adjust upwards so as to fully counteract the extent of the nominal devaluation. In such circumstances the net effect would be to leave internal and external price relativities unchanged and to produce a higher level of domestic inflation than that which existed prior to the devaluation.

The available evidence suggests that such price erosion has occurred in many of the African countries which have initiated nominal devaluations over the past few years: their subsequent inability to hold domestic money incomes in check has more than negated the effects of the devaluation [see World Bank 1983: 8-9; IMF 1982; U Tun Wai and Acquah 1982].

This experience suggests that the real need is to analyse the process by which internal prices adjust in response to an exchange rate movement, rather than merely to estimate the size of the desirable exchange rate shift itself. It remains true that movement in the nominal exchange rate is a potent instrument for achieving shifts in short-term price relativities. But the process by which these shifts can be sustained in the longer term, i.e., by which domestic groups can be forced to accept the new real income relativities imposed by the nominal exchange rate adjustment - becomes the most important part of the analysis of this aspect of domestic policy reform. It should not be surprising -if the cause of the problem is the existence of a sustained differential between national and world inflation rates - that its solution should remain elusive if the only instrument used to tackle it is the exchange rate, rather than instruments designed to address the underlying causes of the inflation rate differential itself.

The potential for achieving real effective devaluation will differ between countries and time periods. In some countries the crucial variable will be the power of labour to protect the real value of wages and salaries. In the two country cases of Kenya and Mauritius examined by Godfrey (1984) the data suggest that while final prices offset all or part of the effects of devaluation, wage and salary rises were not a substantial factor in these increases. While this might have been caused by a time-lag in the adjustment process, it suggests that, at least ad interim, the main benefits of devaluation accrued to the employers of labour, with the self-employed (including those in the agricultural sector) remaining little better off, and the main burden being shouldered by employees. The conditions for achieving an effective devaluation thus depend strongly upon the characteristics of domestic labour markets and production structures, and perhaps equally strongly - upon the disposition of power and influence amongst competing interest groups. More country-based studies incorporating economic, historical and political analysis are required in order to explore the nature and diversity of these relationships. Without the benefit of such analyses, judgements to the effect that particular countries should nominally devalue by a particular amount cannot be expected, on average, to produce helpful results.

\section{Conclusion}

Structuralist theorists have tended not to give much attention to agricultural price policy - either in their attempt to explain the causes of poverty, or in their prescriptions for its alleviation. This has arisen in part from the need to move beyond the static framework within which price theory traditionally has been based, and from the need to emphasise that the complementary inputs required to enhance output are typically not in elastic supply. Output and incomes, therefore, are clearly constrained by factors which go well beyond the issue of price. Some structuralist writings, however, have adopted the view that there is in any case little room for manoeuvre in changing real agricultural price levels. This was based upon the judgement that the resource costs involved were too great to sustain domestic prices at higher than their corresponding international levels for more than short periods of time. The extent of downward deviation of domestic from international prices was either viewed to be not problematic, or to be a necessary concomitant of raising investible resources for industrialisation.

Recent work by the World Bank and other analysts, however, has demonstrated that the extent of such downward variation is typically very large in SSA. A successful narrowing of these differentials would bring significant welfare benefits in the short-run, and probable further benefits via resource reallocation in the medium to long-run. Several aspects of this debate 
about agricultural pricing policy, however, have been unsatisfactory. First, it has not been properly demonstrated that the real tax burden on the agricultural sector has increased over the 1970 s, as compared with earlier decades, nor, therefore, whether this is a key variable in explaining declining agricultural performance. Second, little attention has been given to finding feasible ways in which this tax burden could be lightened in circumstances where governments already face steep declines in real revenues. Third, and most important, much emphasis has been placed, by advocates of policy reform, upon manipulation of the exchange rate in order to correct relative prices. Although in the short-run the exchange rate is a powerful instrument, exclusive emphasis upon variations in its nominal value risks ignoring the reasons why relative price shifts have been historically imposed, i.e. it ignores the political, economic and social causes of past differentials between domestic and international rates of inflation. These causes will need to be analysed more seriously than hitherto if admonitions to reform domestic policy are to be heeded - or if the reasons for the failure of reform experiments are to be better understood.

\section{References}

Bates, R. H., 1981, Markets and States in Tropical Africa, University of California Press, Berkeley, California
Godfrey, Martin, 1984, "Trade and exchange rate policy in sub-Saharan Africa' IDS Bulletin vol 16 no 3

ILO, 1972, Employment, Incomes and Equality: a Strategy for Increasing Productive Employment in Kenya, Geneva

IMF, 1982, World Economic Outlook, Washington

IDS, 1983, 'Accelerated Development in sub-Saharan Africa: What Agendas for Action?', IDS Bulletin, vol 14, no 1

Please, Stanley, and K. Y. Amoako, 1983, 'Sub-Saharan Africa - the World Bank's "Agenda for Action" Revisited', SID, Nairobi (mimeo)

Sharpley, Jennifer, 1984, 'Kenya: macro-economic policies and agricultural performance', OECD Development Centre, Paris (mimeo)

U. Tun Wai and P. A. Acquah, 1982, 'IMF experience with exchange rate adjustment in African countries', IMF, Washington (mimeo)

World Bank/IDS, 1974, Redistribution with Growth, Clarendon Press, Oxford

World Bank, 1981, Accelerated Development in sub-Saharan Africa: an Agenda for Action, Washington

-1983, 'Sub-Saharan Africa: progress report on development prospects and programs', Washington (mimeo) 